\title{
Estudios de arbovirosis en Colombia en la década de 1970
}

Hernando Groot, Alberto Morales, Margarita Romero, Cristina Ferro, Enrique Prías, Hernando Vidales, Bernardo Buitrago, Víctor A. Olano, Dora Calvache, Gladys Márquez, Patricia de la Vega, Gerzaín Rodríguez

\section{Encefalitis equina venezolana}

Entre 1970 y 1971, se comprobaron focos de encefalitis equina venezolana (EEV) en bosques de los siguientes lugares: Tibú (Norte de Santander), Guachaca (Magdalena), Magangué (Bolívar) y la zona de Rionegro-Puerto Boyacá (Boyacá). Los virus aislados de Tibú, Guachaca y Rionegro-Puerto Boyacá se identificaron como cepas I-D. El virus aislado en Magangué de Mansonia titillans parece pertenecer a la cepa I$D$, de la cual se diferencia por su capacidad para producir viremias altas en caballos, según estudios llevados a cabo en la Unidad de Investigaciones de Mesoamérica (MARU), Panamá. Las cepas de Puerto Boyacá se estudiaron, además, en Bogotá desde el punto de vista de su patogenicidad para el caballo, habiéndose demostrado que carecen de ella. En los equinos experimentalmente infectados por vía subcutánea, se produce apenas una ligerísima viremia que induce inmunidad y hace que los caballos sean, más tarde, resistentes a la infección cuando se les reinocula con cepas reconocidamente equicidas.

La persistencia del foco selvático de Puerto Boyacá está comprobada y se resume por separado. Para ver si igualmente persistía el virus en la región de Tibú, se hicieron estudios allí durante 1976. Esta región es especialmente importante desde el punto de vista epidemiológico, pues, se trata de una de las áreas boscosas vecinas a la parte del sur del Lago de Maracaibo, zona esta última donde se ha

Las investigaciones que se informan a continuación corresponden al programa de arbovirosis y se realizaron por el trabajo combinado de Epidemiología, Laboratorio de Arbovirus, Laboratorio de Virología General, Laboratcrio de Entomología, Laboratorio de Patología y otras secciones del Instituto Nacional de Salud. sospechado la presencia de diversos virus de encefalitis. En el curso de nuestros estudios de 1976, expusimos hámsters centinelas en las márgenes del Río de Oro. De estos animales no se aisló EEV; en cambio, se aisló virus de la encefalitis equina del este de los Estados Unidos.

\section{Puerto Boyacá}

En la región del Magdalena medio se comprobaron los primeros focos selváticos de EEV en Colombia, en los bosques de San Vicente de Chucurí, en 1955, y en Puerto Boyacá en 1958. En ambos casos, el descubrimiento se hizo por el Instituto Carlos Finlay, hoy parte integrante del Instituto Nacional de Salud, mediante el aislamiento del virus de personas que enfermaron en la selva. Desde entonces, se juzgó conveniente adelantar en la región estudios para analizar las condiciones epidemiológicas que determinan allí la presencia del virus feral y para ver las relaciones de éste con el virus epizoótico equicida que ha causado numerosas y graves epidemias y epizootias en todo el país.

Desde abril de 1970 , se inició un estudio longitudinal de larga duración en el Magdalena medio con el propósito de adelantar las investigaciones mencionadas. El área de estudio, denominada Puerto Boyacá, está situada en el municipio del mismo nombre en el departamento de Boyacá y comprende, aproximadamente, una zona en forma de $L$ que se extiende a lo largo de la carretera que conduce desde El Triunfo a El Terminal. La primera rama de la $\mathrm{L}$, con una longitud de $27 \mathrm{~km}$, corresponde exactamante a la porción de la carretera La Dorada-Puerto Boyacá, comprendida entre entre El Triunfo, a orillas de Rionegro y el sitio denominado El Dos 
y Medio, sigue una dirección sur-norte y va paralela al río Magdalena, a corta distancia de éste. La segunda rama, con una longitud de 33 $\mathrm{km}$, hace un ángulo de $90^{\circ}$ con la primera, parte del Dos y Medio en dirección oeste-este y llega hasta el pie de de las estribaciones de la Cordillera Oriental. A lado y lado de la carretera, se encuentran áreas de diversos cultivos y de pastos dedicados a la ganadería, entre las cuales se observan aún pequeños bosques, resios de la selva primitiva que cubría la región hace cincuenta años. En la zona de El Terminal, las áreas de bosque son más numerosas que en la parte vecina a EI Triunfo. En esta útima, los bosquecillos están más esparcidos y aislados en medio de los cultivos y de las praderas.

Los estudios en las zonas boscosas consistieron básicamente en investigaciones entomológicas, en estudios serológicos de animales silvestres y en la búsqueda sistemática del virus, tanto en los mosquitos y en los pequeños mamíferos, como mediante el uso de hámsters centinelas. Igualmente, se hicieron pruebas serológicas de personas y de caballos residentes en las áreas vecinas a los bosques. Los estudios han comprendido dos estapas: una primera, realizada esenciaimente en la zona de El Terminal entre abril de 1970 y abril de 1972, y una segunda, en el bosque denominado Los Corales, sobre la carretera del Dos y Medio a El Triunfo, exactamente a $14 \mathrm{~km}$ al norte de este último lugar, la cual, iniciada en octubre de 1973, se ha venido adelantando ininterrumpidamente y se continúa durante el año de 1977. Igualmente, en la zona de EI Triunfo al Dos y Medio, se han hecho algunos estudios ocasionales en La Piragua, en Los Mangos y en La Esperanza.

Estudios en El Terminal. Las observaciones realizadas en los bosques de la zona mostraron una muy notable permanencia del virus durante los veinticinco meses de estudio y, en especial, durante los veintitrés meses (junio de 1970 a abril de 1972) en los que se usaron hámsters centinelas. En efecto, en este último período sólo durante tres meses (julio, agosto y noviembre de 1971) dejó de comprobarse actividad viral; en cada uno de los veinte meses restantes se comprobó la presencia del virus EEV, bien por aislamiento del virus de los hámsters centinelas o de los mosquitos o por conversión serológica de los roedores silvestres recapturados en el bosque.

Los estudios sobre mamíferos silvestres mostraron el importante papel que juega el ratón conato (Proechimys hendei) en el ciclo epidemiológico del virus. De 110 ejemplares capturados, 23 tenían anticuerpos para EEV. Entre los negativos en una primera captura, fue posible recapturar 17, de los cuales 6 mostraron conversión serológica para EEV. Así, pues, es posible estimar que el $26 \%$ de los $P$. hendei muestra anticuerpos para el virus. Estos hallazgos indican que, además del Proechimys guyanensis, el cual se infecta naturalmente en otro países, otra especie del mismo género, el $P$. hendei puede albergar de manera análoga el virus EEV. En El Terminal, probablemente juegan también papel en la epidemiología del virus, algunos marsupiales como el Didelphys marsupialis, del cual se encontraron 8 ejemplares con anticuerpos entre 83 capturados y Metachirus sp. (3 positivos entre 42). En cambio, en 9 Marmosa sp. y en 11 Caluromys sp. no se encontraron anticuerpos.

Igualmente, se estudió una muestra de los habitantes rurales y de los equinos de la zona comprendida entre El Terminal, el Dos y Medio y Puerto Niño, en la vecindad de este último lugar. En total, se examinaron 50 personas, de las cuales $15(30 \%)$ mostraban anticuerpos para EEV, porcentaje similar al encontrado años atrás en los habitantes de un sitio vecino al foco selvático de San Vicente de Chucurí. Los datos anteriores indican que el hombre se infecta en el área con cierta frecuencia. Pudimos estudiar un caso humano infectado en condiciones naturales en abril de 1971, y del cual se aisló el virus. El paciente presentó un síndrome febril agudo de corta duración, similar al que se observa en las personas que enferman cuando se exponen al virus epizoótico.

De 75 equinos examinados, se encontraron 45 $(60 \%)$ con anticuerpos para EEV. Como estos animales no habían sido vacunados ni existía en 
la región historia de peste loca, se deduce que los equinos se infectaron con los virus selváticos locales, los cuales probablemente no les causaron enfermedad aparente. Igualmente comprobamos, en un caballo localizado cerca del bosque, conversión serológica para virus EEV, sin trastorno patológico apreciable. Estos hechos epidemiológicos están en un todo de acuerdo con las características de los virus aislados del bosque, los cuales se han clasificado como ID y, además han mostrado, en experimentos controlados, su ausencia de patogenicidad para con los caballos inmunes alrededor de focos selváticos puede tener importancia epidemiológica, pues, por su incapacidad de multiplicar el virus es posible que restrinjan las condiciones de su diseminación, obrando así a manera de un verdadero cordon sanitaire natural.

En El Terminal, se capturaron 52.130 mosquitos, de los cuales los más frecuentemente hallados fueron Aedes, Culex, Mansonia, Psorophora, Trichoprosopon y Wyeomyia.

Con los ejemplares capturados, se hicieron 477 grupos de acuerdo con el género y con la especie, cuando tal identificación fue posible. Los grupos se inocularon a ratones para el aislamiento de virus con los siguientes resultados: de un grupo de Psorophora ferox se aisló virus $\mathrm{C}$ y de 13 grupos de diversos mosquitos se aisló virus EEV, así: uno de Culex (Melanoconion) spp. (sobre un total de 42), uno de Culex spp. (sobre un total de 29), uno de Trichoprosopon sp. (sobre un total de 20), dos de Mansonia $(R)$ venezuelensis (sobre un total de 31), uno de Aedes serratus (sobre un total de 58), tres de Aedes (Ochlerotatus) spp. (sobre un total de 51) y cuatro de Aedes fulvus (sobre un total de 18). El aislamiento a partir de Culex (Melanoconion) está de acuerdo con la epidemiología del virus observada en otros países, donde el subgénero Melanoconion es el principal transmisor. Los demás aislamientos tienen interpretación difícil, pues, es posible que los mosquitos se infectaran aprovechando la circunstancia, un tanto artificial, de la presencia de hámsters centinelas en los cuales se estaba multiplicando el virus. Se trataba de una situación fuera de la corriente en la que el hombre había introducido un factor nuevo en la selva, esto es un roedor más, el hámster centinela, cautivo sí, pero, con gran capacidad para multiplicar el virus.

Es interesante anotar que la Sección de Entomología del instituto ha identificado en El Terminal las siguientes especies de Culex (Melanoconion): conspiratur, duni, eastor, elephas, elevator, lucifugus, menytes, phlogistus y taeniopus.

Estudios en Los Corales. El bosque de Los Corales está situado a $14 \mathrm{~km}$ al norte de El Triunfo y tiene una superficie aproximada de 9 hectáreas. Su topografía es quebrada, constituida esencialmente por colinas de baja altura y de inclinación suave, entre las cuales discurre un pequeño riachuelo, especialmente en la época lluviosa. En los alrededores del bosque se encuentran zonas abiertas destinadas a pastoreo de ganado y algunos pantanos. Para detectar el virus en Los Corales, se han usado hámsters centinelas ininterrumpidamente desde octubre de 1973. En esta forma, se ha comprobado la presencia de EEV, primero en forma continua, desde octubre de 1973 hasta octubre de 1974 y, luego, en forma esporádica en agosto, octubre y diciembre de 1975 y en marzo y abril de 1976. El último aislamiento se hizo en abril de 1976. Sin embargo, la presencia del virus en el lugar es más frecuente de lo mostrado por los hámsters, a juzgar por los aisiamientos de virus de los mosquitos y por la conversión serológica de los roedores silvestres recapturados.

En Los Corales, el Proechimys hendei es también el mamífero más comúnmente infectado por el virus. En una ocasión, en octubre de 1974, se aisló el agente infeccioso de su sangre y es el roedor que con más frecuencia muestra anticuerpos para el mismo. De 67 ejemplares, se encontraron 23 con anticuerpos cuando fueron capturados por primera vez y $44 \mathrm{sin}$ anticuerpos. Según el procedimiento seguido, una vez sangrados los animales que se capturaran, se sueltan en el mismo lugar donde cayeron en la trampa. De los encontrados sin 
anticuerpos en la primera captura fue posible recapturar 22, de los cuales 17 ya tenían anticuerpos en la segunda captura. La tasa, pues, de infección de $P$. hendei es muy alta.

Lo mismo que en El Terminal, en Los Corales juegan papel en la epidemiología del virus el Didelphys marsupiales, del cual se encontraron 8 ejemplares con anticuerpos entre 33 capturados y Metachirus sp. (4 entre 20). También se encontraron en Los Corales 8 marmosas con anticuerpos entre 20 capturadas. En estas tres especies se comprobaron, además, varias conversiones serológicas. Sin embargo, de ninguno de los animales estudiados se aisló virus.. Finalmente, se encontraron anticuerpos en un ejemplar de Eira barbara (ulamá), entre dos capturados y en el único Dasypus (armadillo) que cayó en trampa. No se desmostraron anticuerpos en 14 Caluromys (marsupial) ni en un ejemplar de Myrmecophaga (oso hormiguero).

En cuanto a prevalencia de anticuerpos para seres humanos, sólo estudiamos una muestra muy limitada de 9 personas, una de las cuales con resultado positivo. Pudimos, también, observar un caso de infección aguda en un niño que después de haber penetrado al bosque de Los Corales desarrolló una fiebre alta con profunda cefalea. De este paciente se aisló el virus EEV.

Se hizo, también, una encuesta en equinos de las fincas distribuidas a lo largo de la carretera entre El Triunfo y el Dos y Medio con el siguiente resultado: 53 equinos positivos sobre un total de 66 , lo cual corresponde a un $80 \%$. Aquí también, como en El Terminal, la positividad de los caballos se debe atribuir a infección anterior por virus no equicidas.

En Los Corales, se capturaron 51.238 mosquitos entre octubre de 1973 y diciembre de 1976. Los géneros más frecuentemente encontrados fueron Aedes, Culex, Anopheles limatus, Mansonia, Trichoposopon, Wyeomyia y Coquillettidia. Parte de los mosquitos capturados se han usado para intento de aislamiento de virus. En cuatro ocasiones se comprobó incontrovertiblemente la infección natural de mosquitos por el virus EEV como sigue: en dos casos en Culex (Melanoconion) spp., en un caso en Culex (Culex) spp. y en un caso en Trichoprosopon sp. En varias ocasiones se aisló el mismo virus de otros mosquitos, pero, no hay seguridad de si la infección en estos artrópodos era natural o inducido por la presencia en el mismo lugar de hámsters centinelas con virus EEV circulante.

Por último, es interesante notar que se hicieron estudios en un pradera localizada $250 \mathrm{~m}$ por fuera del bosque de Los Corales, los cuales demostraron que en determinados momentos hasta allí llegaron los mosquitos naturalmente infectados.

Estudios en La Piragua. Se estudió este lugar por estar en la inmediata vecindad de El Triunfo, en la orilla izquierda del Rionegro. En La Piragua se hicieron los primeros estudios entre octubre de 1973 y julio de 1974, los cuales demostraron la presencia del virus EEV en tres ocasiones en mosquitos Culex del subgénero Melanoconion. Igualmente se encontro allí evidencia de la infección natural del raton conato (Proechymis hendei): de un total de 15 ejemplares capturados, en 4 se encontraron anticuerpos. Estudios muy limitados realizados en La Piragua en épocas más recientes no han demostrado la presencia del virus.

Estudios en Los Mangos. El lugar denominado Los Mangos está situado al frente de La Piragua, Rionegro de por medio, en la margen derecha de este mismo río. En Los Mangos está situado el pequeño laboratorio de campo que sirve como base para los trabajos de la región, especialmente en los bosque de Los Corales. Se expusieron allí hámsters centinelas entre diciembre de 1975 y abril de 1976, comprobándose actividad del virus de EEV en diciembre, en marzo y en abril. Es esta una demostración más de la salida del virus de los focos selváticos a zonas relativamente vecinas.

Estudios en La Esperanza. En este lugar situado al norte de El Triunfo, se hicieron estudios entre abril y diciembre de 1976, los cuales mostraron actividad del virus EEV, confirmada por conversión serológica de un ratón 
conato en julio del mismo año. En La Esperanza este roedor (Proechymis hendei) juega igualmente un papel importante en la epidemiología del virus.

\section{Estudios de EEV en Armero y Ambalema}

Entre mayo de 1972 y octubre de 1973 se hicieron estudios en dos bosquecillos de segundo crecimiento, localizado el uno a $6 \mathrm{~km}$ al norte de Armero, en las inmediaciones de la Estación de Campo del Instituto Nacional de Salud y el otro en Santo Tomás, Ambalema. Las observaciones consistieron esencialmente en tratar de descubrir actividad viral en períodos en los cuales no se registraron brotes de peste loca, enfermedad que periódicamente se presenta en el lugar. Los estudios, basados en hámsters centinelas, en intento de aislamiento de virus a partir de mosquitos y en estudios serológicos de pequeños mamíferos silvestres, dieron resultados totalmente negativos durante los dieciocho meses de la observación. Es de notarse que los mamíferos silvestres eran totalmente escasos en ambas estaciones, habiéndose encontrado tan sólo algunos ejemplares de Didelphys marsupialis y Sigmodon hispidus. En cambio, cerca de la estación de Armero se encontraron cantidades apreciables de ratones Chúcharos.

La fauna entomológica de Armero y Santo Tomás era igualmente escasa, predominando Aedes scapularis y Psorophora confinnis.

Conviene informar que, algunos meses después de terminado el estudio, se presentó un brote de encefalitis equina en Armero y en Guayabal, con muerte de equinos. Desconociéndose los nidos primarios del virus EEV equicida, esta observación nos permite deducir que el agente causante del brote, probablemente no se originó en los bosquecillos vecinos de Armero y Guayabal, uno de los cuales habíamos estudiado meses antes con resultado negativo. Durante 1975 y 1976 no se presentaron casos de encefalitis equina en Armero ni en Guayabal ni en Ambalema.

\section{Epidemiología de EEV en los Llanos Orientales}

La epidemiología de la encefalitis equina venezolana en los Llanos Orientales de Colom- bia es muy poco conocida. Aunque de vez en cuando se tienen noticias de algunas epizootias, tal como la de Arauca en 1972, en general se desconoce la actividad del virus, bien porque no se hace manifiesto o porque la manera como ataca a los caballos es casi silenciosa, con muertes ocasionales, que no causan mayor alarma y cuya etiología es muy difícil de probar. Esta situación se explicaría por el hecho de que en muchos hatos o fincas llaneras el número de caballos es escaso, encontrándose además dichas fincas a considerable distancia una de otra, lo cual determina un ritmo de transmisión muy lento. En estas condiciones, no es dable observar las epizootias casi exposivas que se registran en zonas con numerosos equinos, en las cuales los animales se encuentran además concentrados.

En los Llanos se ha venido estudiando ininterrupidamente desde 1968 un lugar situado en el límite del municipio de San Martín, contiguo a la parte sur del municipio de Puerto López, en el departamento del Meta. En el sitio, representativo de la región y con poca densidad de equinos, se han venido tomando periódicamente muestras de sangre a un número de diez a quince caballos los cuales nunca han sido vacunados. Allí se combrobó la muerte de un caballo por EEV en junio de 1968. Posteriormente, por estudios serológicos, se demostró la actividad del virus en el segundo semestre de 1973.

Sin este uso de caballos centinelas no se hubiera podido reconocer el ataque del virus a los equinos después de 1968. Los estudios durante 1974, 1975 y 1976 no indicaron presencia del virus. El virus EEV, en efecto, muestra en los Llanos Orientales una actividad mayor que aquella señalada por las epizootias reconocidas.

\section{Epidemiología de EEV en La Guajira}

Llama la atención la frecuencia y la regularidad con que se han presentado epizootias y epidemias de encefalitis equina venezolana en La Guajira. Por estas razones, el instituto inició en 1970 un estudio para tratar de conocer mejor la epidemiología de la efermedad en la península 
y para tratar de descubrir una posible actividad viral durante los períodos interepidémicos. Se han adelantado allí estudios en diversas zonas ecológicas, tales como los bosquecillos de la Sierra de Majayura, los bosque vecinos a Tomarrazón y los maglares de Pájaro, sin que se haya podido demostrar actividad alguna de virus entre brote y brote. En el último lugar se investigaron, especialmente, los Deinoceritis. Durante 1976 no se comprobaron epizootias en La Guajira.

\section{Epidemia causada por el virus selvático de la EEV en Lozanía, Tolima}

Durante 1976 se terminó el análisis de la epidemia observada en Lozanía (altura $330 \mathrm{~m}$ ) entre noviembre de 1973 y febrero de 1974. La enfermedad consistió, básicamente, en fiebre de corta duaración que afectó aproximadamente a la mitad de los 346 habitantes del lugar, una pequeña aldea de 78 casas localizadas en la inmediata vecindad de la laguna artificial de Río Prado, en el Tolima. La laguna, determinada por la represa del mismo nombre, construida para utilización hidroeléctrica, se había llenado en julio de 1972. En 1973, se encontraba cubierta, en la vecindad de Lozanía, de grandes lechugas de agua o pistias ( $P$. striatiotes). Una encuesta retrospectiva, analizada en febrero de 1974 , indicó que durante los tres meses inmediatamente anteriores, $174(50 \%)$ individuos habían sufrido una enfermedad febril compatible con infección por el virus EEV. En la encuesta mencionada se sangraron, además, 75 individuos. De 31 personas con historia de fiebre reciente, 26 (84\%) tenían anticuerpos para EEV; en cambio, de 44 individuos sin antecedentes febriles, sólo un $2 \%$ tenía los mismos anticuerpos, lo cual demuestra buena correlación entre los datos clínicos y los serológicos.

Durante el brote, que alcanzó su clímax a mediados de diciembre de 1973, se aisló el virus de EEV de cuatro pacientes en su fase aguda y en otros tres se hizo el diagnóstico de infección por EEV mediante el estudio de sueros pares. Durante la epidemia no se comprobó enfermedad alguna en ninguno de los 62 equinos existentes en el propio poblado en su inmediata vecindad. Es de advertir, sin embargo, que 55 de estos animales habían sido vacunados previamente contra EEV. Entre los 7 sin vacunar, se encontraron 2 con evidencia serológica de infección reciente por EEV.

Los datos anteriores hicieron sospechar, desde un principio, que el brote podría ser causado por una cepa de EEV no patógena para el caballo. Sólo en 1976 fue posible concluir el estudio de la cepa aislada en Lozanía, la cual fue identificada como 1-D, esto es, del mismo tipo de las encontradas en los focos selváticos colombianos y que hasta ahora no se han mostrado equicidas.

Por lo que a transmisión se refiere, durante el pico de la epidemia, se capturaron numerosos tábanos (Lepicelaga crassipes) que parecían ser los insectos hematófagos predominantes durante el día. De ninguno de los 123 ejemplares capturados, se aisló virus. Sólo en enero de 1974, cuando la epidemia declinaba, se pudo estudiar sistemáticamente la fauna entomológica, habiéndose comprobado que el mosquito dominante en Lozanía era Culex (Melanoconion) aikenii, cuyas larvas abundaban entre la pistia de la laguna vecina. Infortunadamente, no se pudo aislar virus de 417 mosquitos de esta especie que se capturaron.

En cuanto a mamíferos diversos que hubieran podido jugar algún papel durante el brote, es interesante anotar que de los 60 perros existentes en Lozanía, se examinaron 23 en febrero de 1974, de los cuales 15 (65\%) mostraron anticuerpos para EEV, con títulos $\mathrm{HI}$ y CF indicativos de infección reciente.

Resulta imposible considerar en este resumen todas las implicaciones epidemiológicas del brote en mención, en el que probablemente enfermaron por EEV, cepa ID, 146 personas ( $84 \%$ de aquellas 174 con historia de fiebre) $\sin$ que los equinos hubieran jugado un papel en el ciclo. Es posible que el virus hubiera sido introducido por un algún ave acuática a la laguna donde encontró un vector adecuado, el cual lo llevó a la población humana vecina. La duración de la epidemia (aproximadamente tres meses) 
indicaría introducción repetida del virus o establecimiento de un ciclo mosquito-hombremosquito en el cual probablemente habría que incluir también al perro.

Tanto Lozanía como la laguna del Río de Prado están situadas en una región donde no hay zonas boscosas primitivas. A cierta distancia de la laguna se encuentra, sin embargo, un pequeño bosque denominado Cerro Corrales, en el cual, durande marzo y abril de 1975 se expusieron hámsters centinelas y se capturaron mosquitos. Por ninguno de los dos sistemas se pudo demostrar la presencia de virus alguno. En el mismo bosque se capturaron 11 ejemplares de Didelphys marsupialis y tres de Marmosa sp., en ninguno de los cuales se encontraron anticuerpos para EEV.

\section{Aislamiento de virus de EEE en Colombia}

En 1957, el instituto Nacional de Salud encontró evidencia serológica de la presencia del virus de la encefalitis equina del este (EEE) de Estados Unidos en la región de San Vicente de Chucurí. Sin embargo, sólo hasta 1969 se aisió el virus por primera vez en Colombia, en Tumaco, por investigadores de la Universidad del Valle. En 1976, el instituto, en el curso de investigaciones rutinarias de la epidemiología del virus de la encefalitits equina venezolana en Tibú, demostró allí el virus de la EEE, mediante el empleo de hámsters centinelas. El hallazgo tiene particular importancia por tratarse de una zona selvática vecina a regiones, tanto en Colombia como en Venezuela, donde con frecuencia se observan epizootias de encefalistis en los equinos. Hasta el presente, tales epizootias se han atribuido al virus de la encefalitis equina venezolana, sospecha que en varios brotes se ha confirmado por el aislamiento del virus EEV.

La presencia del virus EEE en la región de Tibú, obliga a que en el futuro todos los brotes de encefalitis equina que se presenten en los departamentos de Santander del Norte, del Sur y La Guajira en Colombia, y en los estados de Zulia y Táchira en Venezuela sean necesariamente estudiados en cuanto al agente etiológico se refiere, para poder así establecer las medidas profilácticas indicadas. Tal recomendación debe hacerse extensiva, además, a todo Colombia, ante la presencia hoy día comprobada del virus EEE en tres lugares del país, distantes entre sí: Tumaco, San Vicente de Chucurí y Tibú.

\section{Dengue}

Corresponde al Instituto Nacional de Salud el diagnóstico y la vigilancia de enfermedades virales transmitidas por artrópodos así como adelantar las investigaciones que éstas exijan para aclarar su epidemiología. Dentro de estas responsabilidades, el trabajo se ha centrado, especialmente, en la fiebre amarilla, las encefalitis y el dengue. Esta última enfermedad mereció especial atención en 1976 por razón de las epidemias que ocurrieron en el alto Magdalena y ante el riesgo de que se presentara en el país dengue hemorrágico. Si bien es cierto que parte de la vigilancia de esta enfermedad debe corresponder a otros organismos de salud, ha tenido el instituto Nacional de Salud que asumir la totalidad de la misma, por contar con recursos técnicos más adecuados.

Como consecuencia de la reinfestación por Aedes aegypti que experimentó la parte norte de Colombia en 1969-1972, se desarrolló en la misma región una epidemia de dengue 2 que causó, por lo menos, medio millón de casos en los últimos meses de 1974 y los primeros de 1972. Se calcula que para fines de 1972 , el mosquito había invadido un área de $58.000 \mathrm{~km}^{2}$ con una población urbana de 2'350.000 habitantes. En los dos años subsiguientes el Aedes invadió la parte central del país y el valle del alto Magdalena. Aproximadamente a mediados de 1975 comenzaron a presentarse brotes de dengue en distintos lugares de la zona comprendida, aproximadamente, entre Armero por el norte y Neiva por el sur. Las epidemias se intensificaron en 1976, año en el cual se comprobaron igualmente brotes en distintas ciudades de Santander y en Cucúta. Se comprobó que el agente causal de estas epidemias en el interior del país, por lo menos, en Armero, Girardot y Villeta fue el dengue 3, lo cual obligaba al país a intensificar la vigilancia de 
la enfermedad por cuanto se sospecha con fundamento que la presencia de dos tipos inmunológicos de dengue en un mismo país incrementan significativamente la probabilidad de la aparición del dengue hemorrágico, que puede producir mortalidad hasta del $10 \%$ en los niños, tal como se ha observado en el sureste asiático.

Es imposible estimar con precisión cuántos lugares sufrieron dengue durante 1975 y 1976 así como saber el número de enfermos que en aquellos ocurrieron. Para tener una idea de la magnitud del problema, el instituto adelantó estudios intensivos en la región, en dos lugares de población diferente, Armero (19.600 habitantes) y Utica (2.600 habitantes) así como investigaciones adicionales en Villeta, Girardot, Neiva y aldeas vecinas. Estos estudios se concluyeron en 1976 y mostraron que, por lo menos, el $24 \%$ de la población de Armero y el $52 \%$ de la población de Utica sufrió de dengue.

En los departamentos de Santander, Norte de Santander, Tolima, Huila y las vertientes de Antioquia, Caldas, Cundinamarca y Boyacá que quedan al valle del Magdalena; se calcula que existen 150 cabeceras municipales (con una población total de 1'600.000 habitantes) localizadas a menos de 1.250 metros de altura $y$, por consiguiente, con condiciones favorables para el desarrollo del Aedes aegypti, mosquito vector del dengue. No se sabe cuántos de estos lugares están infestados por el mosquito y cuántos hayan tenido dengue. Algunos datos cualitativos indican que, prácticamente, en todos los municipios de Cundinamarca, Caldas, Tolima y Huila en las condiciones antedichas se ha comprobado la presencia del mosquito trasnmisor o se han comprobado casos de dengue. Como una especulación, nada más, se puede calcular que si el dengue se hubiera presentado en sólo la mitad de la población expuesta al riesgo, y hubiera tenido una tasa de ataque como la de Armero, deberían haber ocurrido alrededor de 200.000 casos de dengue en la parte central de Colombia y en el alto Magdalena durante 1975 y 1976. Obviamente, para este, si para este cálculo se utilizara la tasa de ataque registrada en Utica, los casos deberían haber sido del orden de 400.000 . La primera estimación, basada en los datos más cautos y menos alarmistas, está en completo acuerdo con los datos de la costa atlántica cuatro años antes e indica, una vez más, la gravedad del problema.

\section{Dengue en Armero}

En Armero, ciudad del Tolima con 19.600 habitantes y localizada a 350 metros sobre el nivel del mar, se hizo una encuesta casa a casa, entre septiembre 17 y octubre 2 de 1975, tomándose una muestra representativa de la población para indagar sobre la presencia de casos de dengue o de personas con antecedentes de la misma enfermedad. De las 3.100 casas de la población, se visitaron al azar 351 , en las cuales se analizó la situación de salud de las 2.307 personas que en ellas vivían. En el grupo visitado, se encontraron 30 personas con síntomas de dengue y 538 con antecedentes claros del mismo mal durante los tres meses anteriores, en total 568, lo cual corresponde a un $24,6 \%$ de la muestra examinada. De 25 casos agudos, estudiados en el laboratorio, 19 (76\%) eran, sin duda alguna, infección por el virus del dengue, a juzgar por el aislamiento del virus o por conversión serológica. El virus aislado se identificó como dengue 3 .

Los datos clínicos de los convalecientes se corroboraron con los estudios inmunológicos de más de 500 sueros, los cuales muestran que entre un 30 y un $40 \%$ de la población de Armero experimentó dengue en julio, agosto y septiembre de 1975. La mayor incidencia mostrada por las pruebas serológicas se debe, sin duda, a que una cierta proporción de ellas atestigua infecciones asintomáticas pasadas, las cuales, como hemos demostrado en otros estudios, se pueden observar con el virus del dengue. Ateniéndonos sólo a la enfermedad clínica, es fuerza concluir que el brote tuvo un carácter francamente explosivo y que, por lo menos, 5.000 casos de dengue debieron ocurrir en los tres meses aludidos. Este cálculo se hizo extrapolando al total de habitantes del lugar, el porcentaje de incidencia $(24,6)$ encontrado en la muestra de las 2.307 personas estudiadas. Se 
estima que la tasa de ataque fue de 4 por mil en julio, de 58 por mil en agosto y de 174 por mil en septiembre.

La correlación entre los datos clínicos y de laboratorio se demuestra por el hecho de que el $84 \%(154 / 184)$ de aquella persona convalecientes de una enfermedad febril compatible con el diagnóstico de dengue, se encontraron anticuerpos CF y $\mathrm{HI}$ para este virus. En la mayoría de estos casos, la presencia de anticuerpos confirma una infección reciente por dengue, a juzgar por los hallazgos en las presonas nacidas después de 1952, en las cuales los anticuerpos sólo pueden explicarse como resultado de la exposición al brote de 1975. En efecto, hasta donde van nuestros conocimientos no hubo actividad de ningún virus del grupo B en el área entre 1953 y 1974. En tal grupo de personas nacidas después de 1952, la positividad fue del $80 \%(66 / 83)$. Entre 101 individuos nacidos antes de 1952 hubo 88 (88\%) con anticuerpos, los cuales presentan la actividad del dengue tanto en 1975 como en épocas anteriores a 1952. Sin embargo, se presume que, en la mayoría de los casos, los anticuerpos se originaron o se incrementaron por causa del dengue de 1975, dados los antecedentes clínicos recientes de todas estas personas.

Finalmente, en individuos sin historia de fiebre reciente, se encontraron anticuerpos en $8 \%$ ( $7 /$ 83) de aquellas nacidas después de 1952 y en $49 \%$ (44/92) de los nacidos antes de ese año. El primer grupo, probablemente corresponde a infecciones asintomáticas recientes, mientras que el segunto representa, probablemente en su mayor parte, los anticuerpos adquiridos antes de 1952.

En una segunda encuesta, realizada entre octubre 9 y octubre 17, en el barrio Santander de Armero, en el cual aparentemente se iniciaba el brote, entre 469 personas estudiadas se encontraron $94(20 \%)$ con historia posible de dengue durante los dos meses anteriores.

Además de los 25 casos de fiebre estudiados en el curso de la primera encuesta, se examinaron otros 56 pacientes febriles, en 25 de los cuales se comprobó virus de dengue, por inoculación del suero en cultivos celulares o en mosquitos o por xenodiagnóstico. De las numerosas cepas de dengue aisladas sólo se estudiaron 9 para su clasificación inmunológica definitiva. Todas ellas se identificaron como dengue 3 .

La infestación por Aedes aegypti en Armero en la última quincena de septiembre de 1975 era la siguiente: de 420 casas estudiadas (el 13,5\% de las existentes en la localidad) en 97 se encontraron tanto adultos como formas inmaduras, en 121 sólo adultos y en 43 sólo formas inmaduras. Se puede estimar que el índice de larvas fue de $33 \%$ y el de adultos de $52 \%$. La tasa de ataque de los mosquitos, estudiada en varias ocasiones, nunca fue superior a dos mosquitos hembras por hombre-hora.

\section{Dengue en Utica}

Utica es una pequeña población situada en el departamento de Cundinamarca, a $497 \mathrm{~m}$ de altura, con una temperatura media de $26^{\circ} \mathrm{C}$, enclavada en un estrecho valle del Rionegro, alejada de las carreteras por las cuales se moviliza la mayor parte del comercio y del tráfico del alto Magdalena, razones por las cuales se la escogió para el estudio, al considerársela como un lugar representativo de aquellos poblados relativamente aislados, cuya situación debía estudiarse en forma comparativa con la de una ciudad más grande localizada en el corazón de vías importantes, como es Armero.

En Utica, que tiene una población de 2.271 habitantes, aparentemente el primer caso de dengue ocurrió en mayo de 1976. El instituto adelantó allí un estudio entre octubre 19 y noviembre 26 de 1976, siguiendo la misma técnica utilizada en Armero; a saber, se hizo un encuesta casa a casa, tomando una muestra representativa de la población para indagar sobre la presencia de casos de dengue o de personas con antesedente de la misma enfermedad. De las 473 casas de la población se visitaron al azar 130, donde se analizó la situación de las 809 personas que en ellas vivían. En el curso de la visita, se encontraron se encontraron 17 personas con síntomas de 
dengue agudo y 400 con antecedentes claros del mismo durante los tres meses anteriores. Estos 417 individuos corresponden a un $51,5 \%$ de la muestra examinada. De los 17 enfermos con fiebre, se examinó la sangre a 7 , habiéndose demostrado en todos siete la presencia del virus de dengue, provisionalmente identificado como dengue 3 . De las 400 personas con antecedentes de dengue, se examinó la sangre de 190, habiéndose encontrado 186 $(98 \%)$ con evidencia serológica de dengue anterior. De éstos, 190 individuos, 75 nacidos después de 1952, sólo habían estado expuestos al dengue en 1976. En ellos la positividad fue de $96 \%(72 / 75)$. En aquellas personas, también con antecedentes febriles recientes, pero nacidos antes de 1952, la positividad fue del 100\% (114/ 115). Este grupo estuvo expuesto al dengue en 1976 y antes de 1952. Treinta y cinco de los 114 positivos mostraban una reacción serológica secundaria lo cual indica infección reciente por el virus del dengue. En esta forma, los datos de laboratorio confirman totalmente los datos clínicos e indican que, por lo menos, a lo largo de un período de tres meses la mitad de los habitantes de Utica sufrió de dengue. Se estima que la tasa de ataque fue de 21 por mil en agosto, del 262 por mil en septiembre y del 206 por mil en octubre. En novienbre, la tasa de ataque disminuyó: fue del 13 por mil en 26 días. Se trató, pues, de una verdadera epidemia explosiva, con caracteres mucho más severos que la de Armero.

Es interesante anotar que los datos epidemiológicos de Armero y de Utica son las primeras descripciones de grandes epidemias de dengue que se hacen teniento en cuenta las múltiples variables que estudió el instituto.

En Utica, durante la encuesta de las 130 casas, se encontraron 45 con larvas y adultos, 10 con sólo larvas y 56 con sólo adultos de $A$. aegypti. En esta forma se puede calcular que, el índice de larvas fue de $42 \%$ y el índice de adultos de $78 \%$. Sólo 20 casas (15\%) se encontraron libres del mosquito. El índice de Breteau fue de $17 \%$. En cada una de las 130 casas, un hombre adiestrado buscó mosquitos adultos durante 15 minutos exactamente, en tal forma que, en total, se hicieron capturas durante 1.950 minutos. En estas capturas se recolectaron 258 hembras y 239 machos de Aedes aegypti; lo que corresponde, respectivamente, a 1,9 y 1,8 mosquitos por 15 minutos-hombre.

\section{El xenodiagnóstico en el diagnóstico del dengue}

Uno de los problemas en el diagnóstico del dengue consiste en la dificultad para aislar el virus de los casos agudos. Los métodos corrientes se basan en inoculaciones del suero en líneas celulares adecuadas, especialemente LLCMK2 y, más recientemente, en la inoculación intratorácica del suero en Aedes aegypti o Aedes albopictus. Sin embargo, la técnica de la inoculación en los mosquitos, aunque sencilla, puede no estar al alcance de varios laboratorios. En los mosquitos inoculados se desarrolla el virus, el cual es posible demostrarse por inmunofluorescencia o por prueba de fijación de complemento o por inoculación del mismo material del mosquito en células. Nosostros hemos explorado la posibilidad de emplear el xenodiagnóstico, que tiene la ventaja de evitar la inoculación del mosquito. Sin embargo, este procedimiento tiene teóricamente el inconveniente de ofrecer una barrera al desarrollo del virus en los tejidos del artrópodo, como es la pared estomacal del propio insecto. Es posible, quizás, que cuando se usan cepas suficientemente susceptibles de Aedes aegypti, esta desventaja no resulte muy grande.

Hemos estudiado el xenodiagnóstico comparativamente con otras técnicas para el aislamiento del virus del dengue, en pacientes con dengue comprobado o con síntomas sospechosos de la misma enfermedad. En cada caso se hizo el xenodiagnóstico simultáneamente con una toma de sangre para separar suero con el objeto de buscar más tarde en éste el virus, mediante la inoculación en subtratos apropiados. El xenodiagnóstico se hizo haciendo picar al enfermo por 5 a 12 hembras adultas de Aedes aegypti criadas en el laboratorio, con una edad de 32-72 horas y que nunca se habian alimentado antes de sangre. Diez días más tarde, habiendo mantenido los insectos a $32^{\circ} \mathrm{C}$ de temperatura, en un ambiente de humedad del 
$70 \%$, se examinaron las cabezas de los Aedes con la técnica de la inmunofluorescencia directa, empleando suero humano inmune de alto título para dengue 2, para dengue 3 y para otros agentes del grupo B. Si una o más de las cabezas exhibía fluorescencia típica, el xenodiagnóstico se consideraba positivo. Si todas las cabezas eran negativas, se examinaba entoces el tórax; si en éste había fluorescencia, la prueba se consideraba igualmente positiva.

En total, se examinaron 60 pacientes por xenodiagnóstico y por inoculación de suero en células LLCMK2 habiéndose encontrado 46 $(77 \%)$ positivos para el primer procedimiento y $26(46 \%)$ para el segundo. La diferencia es estadísticamente significativa. De estos 60 pacientes, se examinaron 37 ; además, mediante el procedimiento de inocular su suero intratorácicamente en $A$. aegypti. Los resultados de los 37 casos, que son, pues, estrictamente comparables, fueron los siguientes: $33(89 \%)$ positivos por inoculación del suero en mosquitos, 31 (84\%) positivos por xenodiagnóstico y $15(41 \%)$ positivos por inoculación del suero en las células LLCMK2.

Es evidente que, por 10 menos en las condiciones de nuestros mosquitos y pacientes, el xenodiagnóstico es aproximadamente tan sensible para detectar el virus en los Aedes, sin tener las dificultades técnicas del último procedimiento. El xenodiagnóstico es evidentemente más sensible que la inoculación en células LLCMK2 para el diagnóstico del dengue.

En el estudio de los xenodiagnósticos positivos observamos que sólo en pocos casos la totalidad de los mosquitos examinados mostró fluorescencia. Además, en varias ocasiones se demostró fluorescencia en tejido torácico, pero no en las preparaciones de cabeza. Se siguen estudiando cuantitativamente estos fenómenos para ampliar la información al respecto.

La inmunofluorescencia para la detección de la infección natural de $A$. aegypti por virus de dengue

Tradicionalmente se han empleado los métodos de captura de mosquitos e inoculación de los mismos en cultivos celulares con el propósito de hacer estimaciones muy crudas sobre la proporción de mosquitos que puedan encontrarse infectados por dengue en la naturaleza, en el curso de las epidemias. En general, se inoculan pools con cantidades variables de mosquitos, lo cual limita la medida exacta de dicha proporción. Tal procedimiento usamos, por ejemplo, en Montería y Buenavista (departamento de Córdoba) en 1972, cuando intentamos aislamiento de virus de 27 pools de A. aegypti que en total contenían 484 mosquitos. En cada pool había un número variable de mosquitos, entre 3 y 51 . Se encontraron 9 pools positivos, lo cual muestra una infección muy alta en términos de pools, 9 de 27 , o sea un $33 \%$. Sin embargo, los resultados apenas permiten deducir que, cuando menos, el 1,9 de los mosquitos estuvieran infectados, sobre la base que en cada pool sólo hubiera un mosquito infectado, esto es 9 mosquitos entre 484. Como es posible que en los pools positivos hubiera habido más de un mosquito infectado, no es inverosimil pensar que, en la práctica, la proporción de mosquitos con virus de dengue fuera mucho más alta que $1,9 \%$.

Por las razones anteriores decidimos estudiar individualmente, por la técnica de la inmunofluorescencia, mosquitos capturados en varias poblaciones durante epidemias de dengue caracterizadas por altas tasas de ataque. Se hicieron 4 recolecciones de Aedes aegypti en casas seleccionadas al azar, en las que obviamente, por razones de la epidemia en curso, una proporción variable de personas sufría dengue o lo había sufrido en meses anteriores. En una primera colecta, realizada en Armero simultámeamente con la encuesta que mostró en el hombre una tasa de ataque del $24,6 \%$ a lo largo de tres meses, se capturaron $360 \mathrm{~A}$. aegypti hembras, de los cuales 20 (56\%) mostraron fluorescencia positiva. En una segunda colecta, realizada también en Armero, en el barrio Santander, de 167 mosquitos 6 $(3,6 \%)$ mostraron fluorescencia positiva. Una tercera colecta se llevó a cabo en Guayabal (Tolima), en el curso de una epidemia de dengue cuya tasa de ataque se desconoce: allí de 34 Aedes sólo $1(2,9 \%)$ fue positivo. La cuarta colecta se hizo en Villeta donde tampoco hay 
datos exactos sobre la tasa de ataque, aunque se presume que fue alta. En esta población, de 149 mosquitos, $11(7,4 \%)$ fueron positivos. Además, en Armero se capturaron 61 mosquitos en habitaciones en las cuales se sabía habían ocurrido casos de dengue en las semanas inmediatamente anteriores: 4 Aedes $(6,7 \%)$ mostraron fluorescencia.

Interesa consignar, además, que de tres mosquitos capturados en la naturaleza en el curso de las epidemias relatadas se hizo intento de aislamiento de virus por inoculación en células y mosquitos, habiéndose recuperado el virus de dengue 3 en todas las ocasiones.

Los datos anteriores, pues, son claramente demostrativos de que una proporción apreciable de mosquitos puede infectarse por el virus del dengue durante las epidemias. La tasa de infección del mosquito indica el alto nivel de eficiencia con que el Aedes aegypti puede transmitir el dengue. El método de la inmunofluorescencia, al permitir calcular con precisión la tasa de infección de los mosquitos, puede ser útil para estudiar la dinámica del virus durante las epidemias $y$, en general, para comprender mejor la epidemiología de la enfermedad.

\section{Estudios clínicos}

En el curso de la epidemia de dengue 3 en Girardot, se hizo un estudio clínico sistemático de pacientes con el propósito de conocer mejor la sintomatología de la enfermedad y de tratar de detectar signos que pudieran anunciar la presencia de complicaciones, en especial, el choque y las hemorragias. El estudio incluyó examen clínico, cuadro hemático, hematrocrito y medida del número de plaquetas.

Puede resumirse que, en general, el cuadro clínico correspondió al comúnmente observado en el curso de esta enfermedad, con la excepción de que en Girardot fueron muy frecuentes las náuseas, el vómito y la faringitis. Fue notable también la hipotensión observada en la mayoría de los pacientes así como la presencia del signo positivo del torniquete, el cual se registró en un tercio de los enfermos. En los casos estudiados, el hematocrito fue normal así como el número de trombocitos.

Tanto en Girardot como en Armero y en otras poblaciones del alto Magdalena, se hicieron esfuerzos para tratar de encontrar signos indicadores de síndrome de choque y de dengue hemorrágico, afortunadamente, con resultados negativos. Hasta donde van nuestros conocimientos, hasta ahora, no se han informado en Colombia casos de estas graves complicaciones.

\section{Diagnóstico del dengue agudo por la identificación del virus en los leucocitos}

La posibilidad de demostrar la presencia de algunos virus o antígenos virales en los glóbulos blancos de la sangre periférica del hombre se ha comprobado en diversas ocasiones. Hasta donde van nuestros conocimientos, en varios casos de dengue hemorrágico observados en el sureste asiático, se ha encontrado el virus del dengue en los leucocitos periféricos. Nosotros estamos estudiando un método para diagnosticar los casos agudos de dengue tomando al paciente sangre con heparina, concentrando los leucocitos y tiñéndolos con un anticuerpo conjugado con fluoresceína. Los resultados hasta ahora son prometedores, pero hace falta completar algunos detalles del procedimiento para eliminar ciertas reacciones inespecíficas que pueden ocurrir. Al perfeccionarse el sistema, se habrá logrado un avance considerable en el diagnóstico de la enfermedad, puesto que en el curso de muy pocas horas se podrá hacer el diagnóstico de dengue, o según sea la situación epidemiológica, de infección por alguno de los arbovirus del grupo B de Casals.

\section{Fiebre amarilla}

Encontrándose gran parte del país reinfestada por el Aedes aegypti y hallándose varias de las poblaciones y ciudades invadidas por el mosquito cerca de los focos de fiebre amarilla sevática, durante el año se intensificó la vigilancia de esta enfermedad con el propósito de detectar oportunamente el virus en las selvas donde pudiera estar activo y así recomendar las medidas preventivas adicionales del caso. Para 
lograr este objetivo, básicamente se continuó desarrollando el programa de viscerotomía, el cual está hoy complementado con las autopias rutinarias que sistemáticamente se hacen en numerosos hospitales regionales y de provincia: Durante el año se examinaron en el instituto 637 muestras de hígado, de las cuales 20 fueron positivas para fiebre amarilla. La procedencia de estos casos fue la siguiente: piedemonte de los Llanos Orientales de la región de Yopal: 12 casos, San Vicente del Cagúan (Caquéta) 3 casos y en la hoya del río Magdalena, 5 casos a saber: 3 en San Vicente de Chucurí (Santander) 1 en Victoria (Caldas) y 1 en Yacopí (Cundinamarca). Además, en Yopal se comprobaron tres casos más por examen serológico de muestras pares.

Obviamente el brote más importante fue el de las vecindades de Yopal, donde enfermó, con síntomas de fiebre amarrilla, un número desconocido de personas, de las cuales por lo menos 35 se hospitalizaron en el hospital de Yopal. Doce pacientes fallecieron y en ellos el diagnóstico se hizo por el examen histológico del hígado. A quince de los sobrevivientes se les practicó examen serológico con los siguientes resultados: tres casos en que se pudieron examinar muestras pares, mostraron conversión serólogica patognomónica para fiebre amarilla; de doce casos de los cuales se les examinó una sola muestra de sangre, en todos se demostraron anticuerpos para fiebre amarilla, a título alto en seis y a título bajo en los restantes seis.

El brote de Yopal, conjuntamente con el de San Vicente del Caguán, hace parte de la onda periódica de fiebre amarilla que se vive registrando recientemente en la periferia de la gran hoya Orinoco-Amazonas, onda que en 1975 se hizo presente en la región de Puerto Asís (2 casos) y en 1974 en San Juan de Arama (26 casos) y en las estribaciones del municipio de Ubalá que caen a los Lianos Orientales ( 3 casos).

Los casos de San Vicente de Chucurí atestiguan una vez más, la presencia periódica del virus de fiebre amarilla en esta región relativamente minúscula si se la compara con la gran selva amazónica, y donde todavía no están suficientemente claros los mecanismos que expliquen, bien la reintroducción periódica del virus, por lo menos, a la zona de las estribaciones de la cordillera 0 bien la permanencia del mismo con períodos de silencio que alternan con períodos de actividad. En efecto, en la zona de San Vicente de Chucurí, donde la viscerotomía ha operado continuamente desde 1935, 95 casos fatales se han diagnosticado entre 1935 y 1976. Los casos han tenido una distribución irregular en el tiempo, pero hay razón para presumir que, con base en los datos meramente cualitativos de la viscerotomía, durante los 42 años de referencia, el virus ha mostrado probablemente 13 períodos de actividad que han alternado con períodos de silencio de longitud variable. Es posible que los casos de 1976 hagan parte de la misma actividad detectada en 1975, cuando se registraron 6 defunciones por fiebre amarilla en el lugar, actividad que se ha venido a registrar después de 6 años de silencio, pues el último caso anterior a 1975 fue en marzo de 1969.

El enfermo de Victoria, Caldas, reviste particular importancia pues vino a morir a La Dorada, por ese entonces infestada por Aedes aegypti. Es un ejemplo más de los movimientos de los enfermos de fiebre amarilla desde los focos selvátivos hasta las localidades infectadas por el Aedes, lo cual determina siempre el riesgo de urbanización de la enfermedad y el posible desarrollo de epidemias en las ciudades. Afortunadamente, el enfermo venido desde los bosques de Victoria no determinó problema alguno en La Dorada. Aunque tal vez el riesgo arriba descrito se aminora cuando los pacientes que llegan de la selva a la ciudad lo hacen en estado avanzado de su enfermedad, con poco o ningún virus en la sangre, el peligro de brotes urbanos siempre subsiste cuando tales migraciones ocurren.

Competencia del Aedes aegypti para transmitir el virus de la fiebre amarilla

Estudios recientes han demostrado que la capacidad de los artrópodos vectores para transmitir los virus puede variar de acuerdo con 
la cepa del virus. Entre los flavivirus, el fenómeno se ha demostrado con los virus del dengue y con cepas de varios orígenes de Aedes albopictus, las cuales muestran diferente capacidad de inf́ectarse según su procedencia geográfica.

Interesa estudiar la competencia del Aedes aegypti prevalente actualmente en Colombia para transmitir el virus de la fiebre amarilla y, en esta forma, contribuir a una valoración más adecuada del riesgo de urbanización de la enfermedad. Se hicieron estudios preliminares usando una cepa de virus aislada a fines de 1974 de un caso humano de La Macarena y una cepa de Aedes proveniente de capturas hechas en Sahagún,
Córdoba, en enero de 1972, la cual corresponde al tipo de mosquito que reinvadió al país en 1969. Los ensayos se efectuaron haciendo que el mosquito picara a ratones lactantes infectados con el virus y luego, después de un intervalo adecuado, a ratones lactantes sanos. En esta forma, se lograron varias trnasmisiones de virus, demostrándose así la capacidad del Aedes de Sahagún para llevar la enfermedad de un vertebrado infectado a uno sano. Sin embargo, el método no permite medir diferencias sutiles de la capacidad transmisora, por lo cual los ensayos se deben repetir usando como fuente de virus primates no humanos. 